\title{
KARAKTERISTIK KAYU LAPIS SAWIT
}

\section{(Characteristics of Oil Palm Plywood)}

\author{
Oleh/By : \\ Jamal Balfas \\ Pusat Litbang Hasil Hutan, Jl. Gunung Batu No. 5 Bogor Telp./Fax. 8633378/8633413
}

Diterima 23 Pebruari 2009, disetujui 7 April 2009

\begin{abstract}
Indonesian plywood industry has drastically declined in the last few years. The main reason causing the change is simply the availability of raw materials. On the contrary, Indonesia possesses huge woody materials from the oil palm plantations. This new material bas never been used effectively for any wood industries. This study examined technical possibility of using oil palm wood for plywood production. The experiments were accomplished in two separate factories, which one belongs to PT. Sumalindo, East Kalimantan and the other belongs to PT. Asia Forestama Raya, in Riau. The two factories have different production facilities. Other source of variations which were examined in this study includes number of ply and ply composition of the panel. Physical and mechanical properties of the panels were tested to evaluate panel quality.

Results indicated that effectivity and efficiency of oil palm plywood production were significantly determined by production facilities. The first factory produced better quality but lower recovery than the second one. Physical and mechanical characteristics of the panels were markedly affected by production process, number of ply and the ply composition. The physical and mechanical qualities of the panels decreased with increasing number of ply and oil palm veneer composition. There was a positive correlation between panel density and bond strength. The oil palm plywood produced in this experiment could be used for interiorpurposes.
\end{abstract}

Keywords: Oilpalm, plywood, physical, mechanical

\begin{abstract}
ABSTRAK
Industri kayu lapis nasional mengalami penurunan secara drastis dalam beberapa tahun terakhir. Alasan utama penyebab perubahan tersebut adalah masalah ketersediaan bahan baku. Pada sisi lain, di Indonesia terdapat bahan berkayu dari perkebunan sawit secara berlimpah, dan sampai saat ini belum digunakan untuk keperluan industri perkayuan. Dalam penelitian ini dilakukan evaluasi teknis terhadap penggunaan kayu sawit sebagai bahan baku industri kayu lapis. Penelitian ini dilakukan melalui dua unit percobaan, yaitu di PT. Sumalindo, Kalimantan Timur dan P'T. Asia Forestama Raya, Riau. Kedua unit pabrik memiliki fasilitas produksi yang berbeda. Sumber keragaman lain yang diamati dalam penelitian ini adalah jumlah lapisan dan komposisi lapisan. Dalam penelitian ini diamati parameter fisis dan mekanis sebagai kriteria kualitas panel.

Hasil penelitian menunjukkan bahwa efisiensi dan efektifitas produksi panel kayu sawit secara nyata dipengaruhi oleh faktor fasilitas produksi. Pabrik pertama menghasilkan kualitas produk yang lebih baik namun memiliki efisiensi yang lebih rendah dibandingkan dengan pabrik kedua. Karakteristik fisis dan mekanis pada panel kayu sawit dipengaruhi secara nyata oleh faktor proses produksi, jumlah lapisan dan komposisi lapisan. Kualitas fisis dan mekanis panel kayu sawit menurun
\end{abstract}


dengan pertambahan jumlah lapisan dan komposisi venir kayu sawit. Terdapat korelasi positif antara nilai kerapatan dan keteguhan rekat pada panel kayu lapis sawit. Panel kayu lapis yang dihasilkan dalam percobaan ini dapat memenuhi kualifikasi produk interior.

Kata kunci: Kelapa sawit, kayu lapis, fisis, mekanis

\section{PENDAHULUAN}

Industri panil kayu Indonesia mengalami penurunan secara drastis dalam beberapa tahun terakhir, sebagai salah satu implikasi dari pelaksanaan program restrukturisasi industri kehutanan, yang memuat kebijakan "Soft landing" pada tahun 2002. Menurut laporan data Asosiasi Panil Kayu Indonesia (APKINDO) yang diuraikan oleh Purwanto (2008), jumlah anggota asosiasi tersebut pada periode puncak produksi tahun 2003 mencapai 130 perusahaan dengan kapasitas produksi sekitar 6,1 juta $\mathrm{m}^{3} /$ tahun. Namun pada tahun 2006 jumlah anggotanya menurun sekitar $50 \%$, dan dari jumlah tersebut hanya 19 unit perusahaan yang berproduksi secara normal dengan volume kumulatif sekitar 1,54 juta $\mathrm{m}^{3} /$ tahun. Perubahan ini praktis menurunkan devisa, pajak, lapangan kerja serta kontribusi lainnya dari sektor industri panil kayu lapis nasional. Faktor dominan yang menyebabkan perubahan tersebut adalah defisit pasokan bahan baku kayu bulat baik dari hutan alam, hutan tanaman, hutan rakyat maupun sumber kayu lainnya.

Industri panil kayu lapis nasional dalam beberapa tahun terakhir telah memanfaatkan segala jenis kayu dari berbagai sumber, seperti sengon, randu, kemiri, mangium, karet dan kelapa. Bahkan jenis kayu yang selama ini tidak digunakan dari kelompok jenis mahang (Macaranga spp.) telah dimanfaatkan menjadi venir inti (core veneer) pada beberapa industri kayu lapis di Sumatera. Keterbatasan pasokan bahan baku industri kayu telah mendesak kenaikan harga kayu bulat sampai pada batas marginal yang mengancam kelangsungan industri kayu nasional. Sebagai contoh, harga kayu bulat sengon per $\mathrm{m}^{3}$ pada tahun 2003 hanya sekitar Rp 100.000, sedangkan pada tahun 2008 harganya telah mencapai Rp 600.000. Sementara harga produk kayu lapis dalam periode yang sama di pasar internasional mengalami penurunan. Hal ini menyebabkan porsi biaya bahan baku pada struktur biaya produksi kayu lapis melonjak dari sekitar 30\% pada tahun 2003 menjadi sekitar 55\% pada tahun 2008 .

Uraian di atas menggambarkan bahwa kelangsungan industri kayu lapis nasional saat ini sangat ditentukan oleh faktor harga kayu bulat. Pada sisi lain kemungkinan penurunan harga kayu bulat sukar diharapkan karena sumber kayu tersebut makin lama makin jauh dari lokasi pabrik, sehingga komponen biaya angkutannya cenderung terus meningkat. Permasalahan ini perlu ditanggulangi secepatnya agar terhindar dari risiko pemutusan kerja karyawan dan kerawanan sosial. Satu solusi yang paling mungkin dilakukan adalah menggunakan bahan berkayu lain yang bernilai murah dan tersedia dalam jumlah besar. Alternatif ini hanya mungkin dipenuhi melalui pemanfaatan kayu sawit sebagai bahan baku industri kayu lapis. Bahan kayu ini sama sekali belum digunakan oleh industri perkayuan nasional, sementara puluhan juta meter kubik limbah batang setiap tahun terbuang percuma di areal peremajaan kebun sawit. 
Tulisan ini melaporkan hasil uji coba kayu sawit sebagai bahan baku kayu lapis yang telah dilakukan selama dua tahun terakhir pada dua lokasi pabrik berbeda di Samarinda dan Riau. Pada bagian ini dilaporkan aspek teknis yang meliputi aspek proses produksi dan karakteristik hasil produksi kayu lapis.

\section{METODE PENELITIAN}

\section{A. Lokasi Penelitian}

Penelitian ini dilakukan pada dua unit pabrik kayu sawit dalam selang waktu sekitar dua tahun. Penelitian pertama dilakukan di pabrik kayu lapis PT. Sumalindo, Loh Janan, Kalimantan Timur pada tahun 2006. Penelitian ke dua dilakukan di pabrik kayu lapis PT. Forestama Raya (Group RGM), Rumbai, Riau pada tahun 2008.

\section{B. Bahan Penelitian}

Bahan kayu bulat sawit yang digunakan dalam penelitian pertama berasal dari tanaman sawit berusia 24 tahun di Kabupaten Pasir, Provinsi Kalimantan Timur. Bahan kayu bulat sawit pada percobaan ke dua berasal dari perkebunan sawit berumur sekitar 22 tahun milik PTP Nusantara V, Riau. Bahan pembantu yang digunakan dalam penelitian ini diantaranya adalah perekat Urea Formaldehida (UF), dempul, pita gulung (reeling tape) dan pita rekat (gummer tape).

\section{Metode Pengolahan}

Proses pengolahan kayu lapis sawit secara umum mengikuti tahapan proses produksi kayu lapis konvensional dengan beberapa tambahan modifikasi pada peralatan dan tahapan produksi. Modifikasi utama yang dilakukan pada peralatan produksi adalah pengaturan sudut pisau kupas yang sesuai digunakan untuk mengupas kayu sawit. Sedangkan modifikasi yang dilakukan terhadap tahapan produksi terdiri dari dua tahap, yaitu pemanasan dan kompresi venir. Kedua tahapan ini sama sekali tidak diperlukan dalam proses produksi kayu konvensional. Pelaksanaan kedua modifikasi dalam penelitian ini pada dasarnya mengikuti fasilitas mesin dan peralatan produksi yang tersedia di masing-masing pabrik. Ukuran tebal venir kayu sawit sebelum kompresi adalah $4 \mathrm{~mm}$. Pada penelitian pertama di PT. Sumalindo proses pemanasan dan kompresi venir dilakukan dengan menggunakan mesin pengering bertekanan (press dryer), sedangkan pada penelitian kedua, proses pemanasan dilakukan pada tanki pemanas (beating tank) dan kompresi venir dilakukan pada mesin kempa panas (bot press). Ilustrasi teknis kedua percobaan produksi kayu lapis di atas secara ringkas disajikan pada diagram Gambar 1 dan Gambar 2.

Proses perekatan pada percobaan pertama menggunakan perekat Urea formaldehida (UF) pada tingkat laburan $32 \mathrm{gr} / \mathrm{sf}^{2}$, sebagaimana lazim digunakan pada produksi panel kayu lapis konvensional, sedangkan pada percobaan ke dua digunakan perekat sejenis dengan tingkat laburan 10\% lebih tinggi atau sekitar $35 \mathrm{~g} / \mathrm{sf}^{2}$. Pengempaan dingin dilakukan pada mesin cold press selama 25 menit pada tekanan $9 \mathrm{Kg} / \mathrm{cm}^{2}$, sedangkan proses kempa panas dilakukan pada mesin hot press selama 10 menit pada tekanan $8 \mathrm{Kg} / \mathrm{cm}^{2}$. Komposisi 
penyusunan venir dalam pembuatan panel kayu lapis dalam percobaan ini terdiri dari 7 dan 11 lapis dengan rancangan komposisi venir sawit 100, 92 dan $82 \%$. Venir lain yang digunakan dalam komposisi tersebut adalah venir kayu kamper dengan ukuran tebal venir 1,46 mm, yang diletakkan pada bagian muka (face) dan belakang (back) panel. Ukuran panel yang dibuat dalam percobaan ini adalah ukuran komersil $(120 \times 240 \mathrm{~cm})$. Pengujian pada panel kayu lapis dilakukan dengan metode yang digunakan oleh pabrik kayu lapis, yaitu standar Jepang, JAS (Anonim, 1993).

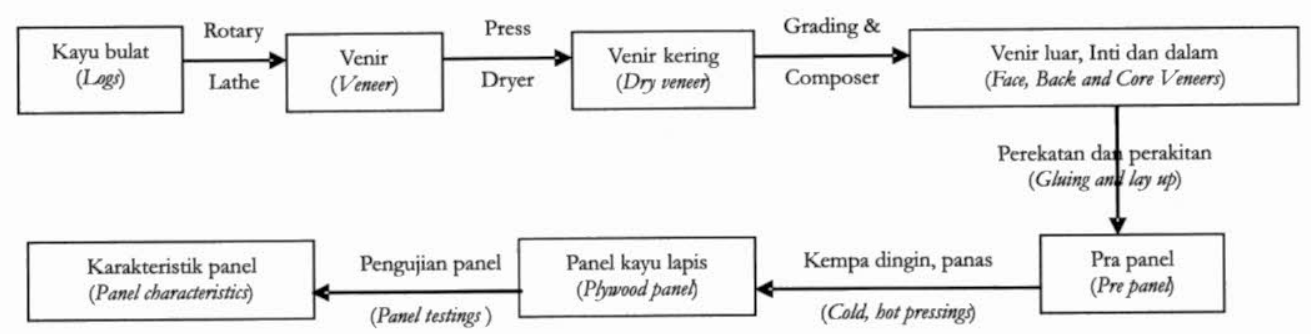

Gambar 1. Diagram proses kerja pada percobaan pertama Figure 1. Working process diagram in the first experiment

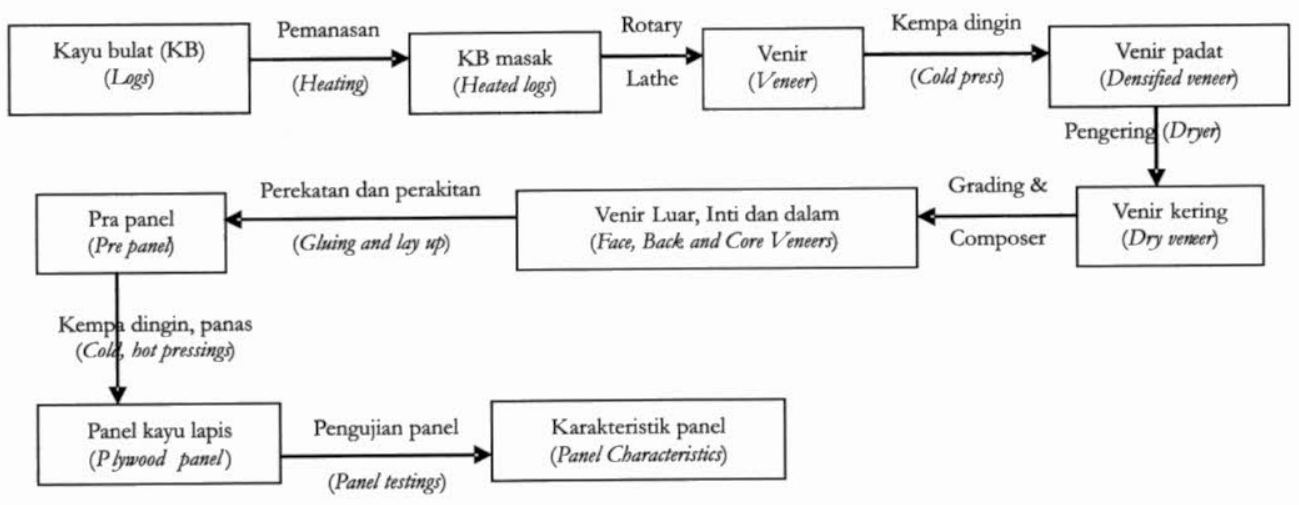

Gambar 2. Diagram proses kerja pada percobaan kedua Figure 2. Working process diagram in the second experiment 


\section{Rancangan Percobaan}

Percobaan ini memiliki tiga faktor utama, yaitu proses produksi, jumlah lapisan dan komposisi lapisan. Proses produksi panel dilakukan secara berbeda menurut fasilitas pengolahan pabrik. Pembuatan panel secara umum dibuat dalam dua kelompok contoh panel menurut perlakuan jumlah lapisan (JL) dan komposisi lapisan (KL). Jumlah lapisan terdiri dari dua taraf, yaitu 7 dan 11 lapis. Komposisi lapisan terdiri dari 3 taraf, yaitu 82, 92 dan $100 \%$ kandungan venir sawit. Masing-masing taraf memiliki ulangan sebanyak 5 buah contoh panel. Untuk mengetahui pengaruh masing-masing faktor di atas terhadap karakteristik panel dilakukan analisis data menurut prosedur faktorial.

\section{HASIL DAN PEMBAHASAN}

Gambaran efisiensi (rendemen) pada proses produksi kayu lapis sawit menurut tahapannya disajikan pada Tabel 1. Proses pemotongan bagian ujung kayu bulat (log) pada tahap awal menyebabkan kehilangan volume sekitar 3\%. Porsi kehilangan pada tahap ini relatif sama dengan kehilangan volume yang terjadi dalam pengolahan jenis kayu lainnya yang berasal dari hutan tanaman maupun kayu rakyat.

Tabel 1. Rendemen pengolahan kayu lapis sawit Table 1. Recovery of oil palm plywood processing

\begin{tabular}{|l|c|c|}
\hline \multicolumn{1}{|c|}{$\begin{array}{c}\text { Tahapan proses } \\
\text { (Processing stages) }\end{array}$} & $\begin{array}{c}\text { Percobaan pertama } \\
\text { (First experiment) }\end{array}$ & $\begin{array}{c}\text { Percobaan kedua } \\
\text { (Second experiment) }\end{array}$ \\
\hline Pemotongan log (Log cutting) & 96,92 & 97,85 \\
\hline Pengupasan (Peeling) & & 36,62 \\
- Rotary lathe & 25,48 & 26,45 \\
- Spindle less & 17,29 & 63,07 \\
- Kumulatif (Cumulative) & 42,77 & 39,51 \\
\hline Pengempaan venir (Veneer pressing) & \multirow{2}{*}{$16,46 *$} & 26,17 \\
\hline Pengeringan (Drying) & 16,21 & 24,62 \\
\hline Pengempaan panas (Hot pressing) & 13,24 & 21,55 \\
\hline Pemotongan dan pengamplasan & & \\
(Double sawing and sanding) & & \\
\hline
\end{tabular}

Keterangan (Remarks): * Menggunakan mesin press-dryer (Using press-dryer machine)

Proses pengupasan kayu bulat sawit pada percobaan pertama di PT Sumalindo, yang dilakukan dengan menggunakan sudut kupas sekitar $23^{\circ}$ pada mesin Rotary lathe dan $21^{\circ}$ pada mesin Spindle less cenderung menimbulkan kerusakan pada venir yang dihasilkan, sehingga menyebabkan rendemen venir pada percobaan ini tidak lebih dari $43 \%$. Pengubahan ukuran sudut pisau pada mesin kupas menjadi $19^{\circ}$ dalam percobaan ke dua di PT. Asia Forestama Raya secara efektif dapat meningkatkan rendemen venir menjadi sekitar $63 \%$. Hasil ini menunjukkan bahwa rendemen venir kayu sawit pada tahap awal (sebelum perlakuan kompresi) mendekati nilai rendemen venir kayu tanaman (69-70\%). Namun demikian, hasil 
pengupasan venir kayu sawit akan menjadi lebih baik apabila kecepatan putar (RPM) pada spindle rotary dapat diperlambat sekitar $20 \%$ melalui modifikasi pada bagian penggerak mesin (pulley). Kecepatan putar log pada mesin rotary konvensional bersifat tetap (unudjustable) dan dirancang untuk mengupas kayu tradisional dengan rotasi per menit (RPM) sekitar 160. Kecepatan putar pada mesin tersebut relatif terlalu tinggi bila digunakan dalam pengupasan kayu sawit.

Proses pengempaan dan pengeringan venir pada percobaan pertama terjadi secara bersamaan pada satu unit mesin (press dryer) dan kadar air venir setelah melalui perlakuan tersebut mencapai $6 \%$, sehingga venir mengalami kehilangan volumetris sekitar $26 \%$ dalam press-drying. Pada percobaan kedua perlakuan pengempaan dan pengeringan venir masingmasing menyebabkan kehilangan volume sekitar 24 dan 13\%. Kedua perlakuan tersebut menunjukkan kehilangan volumetris pada venir sawit sekitar $60 \%$ dari volume venir kayu sawit basah. Perubahan dimensi secara drastis pada struktur kayu sawit bersifat unik, serupa dengan struktur kayu kelapa (Balfas, 2007), namun tidak dijumpai pada struktur kayu tradisional baik yang berasal dari hutan alam maupun hutan tanaman. Perbedaan ini terutama disebabkan oleh kandungan air dan jaringan parenkim dalam jumlah besar pada kayu sawit (Balfas, 2006). Pada tahap inilah kompatibilitas (kuantitatif) venir kayu sawit menjadi sangat rendah dibandingkan dengan venir kayu asal hutan tanaman yang sampai tahap kondisi venir kering dapat mencapai rendemen lebih dari 50\%. Namun demikian, perlakuan pengempaan tersebut menghasilkan venir dengan kerapatan struktur lebih dari dua kali kerapatan kayu sawit asal, sehingga memiliki sifat keteguhan longitudinal lebih baik daripada venir kayu hutan tanaman, terutama dari jenis pohon cepat tumbuh.

Dalam tahap pengempaan panel pada mesin hot press terjadi kehilangan volumetris sekitar $0,2 \%$ pada percobaan pertama, yang nilainya relatif kecil dibandingkan dengan 1,5\% pada percobaan ke dua (Tabel 1). Perbedaan ini terutama berkaitan dengan perbedaan kadar air venir setelah proses pengeringan, di mana metode pertama mencapai kadar air 6\%, sedangkan pada metode ke dua hanya sekitar 12\%. Menurut Haygreen dan Bowyer (1985) nilai kadar air venir saat penyusunan panel sangat menentukan besaran penyusutan panel dalam proses pengempaan panas.

Pada tahap pemotongan kedua sisi panel dan pengamplasan permukaan panel terjadi kehilangan volumetris sekitar 3\%, sehingga rendemen kumulatif pada pembuatan panel kayu lapis sawit pada masing-masing percobaan adalah 13,24 dan 21,55\%. Hasil ini menunjukkan bahwa perbaikan pada mekanisme pengolahan kayu sawit dalam percobaan ke dua mampu meningkatkan nilai rendemen pengolahan sekitar $8 \%$ dibandingkan dengan nilai rendemen yang diperoleh pada percobaan pertama. Namun demikian, nilai rendemen tersebut relatif kecil bila dibandingkan dengan rendemen pengolahan kayu tanaman yang berkisar antara 40 sampai dengan 50\% (Iskandar, 2006).

Hasil pengujian laboratoris terhadap karakteristik produk panel kayu lapis sawit pada Tabel 2 menunjukkan bahwa sifat fisis produk tersebut beragam menurut beberapa faktor yang diamati dalam penelitian ini. Hasil analisis keragaman pada Tabel 3 menunjukkan bahwa faktor proses percobaan, jumlah lapisan, komposisi lapisan, serta kombinasi ketiganya berpengaruh sangat nyata $(\mathrm{p}>99 \%)$ terhadap kandungan air pada panel kayu lapis sawit. Sedangkan nilai kerapatan panel hanya dipengaruhi secara nyata $(p>95 \%)$ oleh faktor proses percobaan dan jumlah lapisan, serta kombinasi kedua faktor tersebut. 
Tabel 2. Sifat fisis kayu lapis sawit

Table 2. Pbysical properties of oil palm plywood

\begin{tabular}{|c|c|c|c|c|}
\hline $\begin{array}{l}\text { Percobaan } \\
\text { (Experiment) }\end{array}$ & $\begin{array}{l}\text { Jumlah lapisan } \\
\text { (Number of } p l y)\end{array}$ & $\begin{array}{l}\text { Komposisi lapisan } \\
\text { (Ply composition) }\end{array}$ & $\begin{array}{c}\text { Kadar air, } \% \\
\text { (Moisture content) }\end{array}$ & $\begin{array}{c}\text { Kerapatan, } \\
\text { gr/ } \mathrm{cm}^{3} \\
\text { (Density) }\end{array}$ \\
\hline \multirow{6}{*}{ I } & \multirow{3}{*}{7 Lapis (Plies) } & 82 & 7,05 & 729,14 \\
\hline & & 92 & 7,76 & 726,18 \\
\hline & & 100 & 8,18 & 733,08 \\
\hline & \multirow{3}{*}{11 Lapis (Plies) } & 82 & 8,20 & 696,21 \\
\hline & & 92 & 9,38 & 695,64 \\
\hline & & 100 & 11,04 & 693,93 \\
\hline \multirow{6}{*}{ II } & \multirow{3}{*}{7 Lapis (Plies) } & 82 & 8,41 & 659,73 \\
\hline & & 92 & 8,96 & 661,14 \\
\hline & & 100 & 10,45 & 660,28 \\
\hline & \multirow{3}{*}{11 Lapis (Plies) } & 82 & 9,62 & 627,36 \\
\hline & & 92 & 10,14 & 628,05 \\
\hline & & 100 & 10,85 & 627,71 \\
\hline
\end{tabular}

Tabel 3. Analisis keragaman pada sifat fisis panel kayu lapis sawit

Table 3. Analysis of variances on physical properties of oil palm plywood

\begin{tabular}{|c|c|c|c|}
\hline \multirow{2}{*}{$\begin{array}{l}\text { Sumber keragaman } \\
\text { (Source of variances) }\end{array}$} & \multirow{2}{*}{$\begin{array}{l}\mathrm{db} \\
(d f)\end{array}$} & \multicolumn{2}{|c|}{ F- Hitung (F-Calculated $)$} \\
\hline & & $\begin{array}{c}\text { Kadar air } \\
\text { (Moisture content) }\end{array}$ & $\begin{array}{c}\text { Kerapatan } \\
\text { (Density) }\end{array}$ \\
\hline $\begin{array}{l}\text { EXP = Percobaan } \\
\text { (Experiment) }\end{array}$ & 1 & 531,048 sn & 296,594 sn \\
\hline $\begin{array}{l}\text { NUMBER = Jumlah lapisan } \\
(\text { Number of ply) }\end{array}$ & 1 & 811,527 sn & 99,684 sn \\
\hline $\begin{array}{l}\text { COMP = Komposisi lapisan } \\
\text { (Composition of ply) }\end{array}$ & 2 & 453,413 sn & 0,776 sn \\
\hline EXP $*$ NUMBER & 1 & 89,319 sn & $1,028^{\mathrm{sn}}$ \\
\hline EXP $*$ COMP & 2 & 4,832 sn & $0,957 \mathrm{sn}$ \\
\hline NUMBER * COMP & 2 & $6,771 \mathrm{sn}$ & 0,929 sn \\
\hline EXP $*$ NUMBER * COMP & 2 & $54,415^{\text {sn }}$ & $1,390^{\mathrm{sn}}$ \\
\hline Galat (Error) & 48 & & \\
\hline
\end{tabular}

Keterangan (Remarks): $\mathrm{db}(\mathrm{df})=$ derajat bebas (degrees of freedom); $\mathrm{sn}=$ sangat nyata $($ very significant $)$; tn = tidak nyata (not significant)

Kadar air dan kerapatan panel kayu lapis sawit pada percobaan pertama memiliki nilai lebih rendah daripada percobaan ke dua (Tabel 2). Perbedaan kedua sifat fisis tersebut terutama berkaitan dengan kondisi venir yang dihasilkan dari masing-masing proses percobaan. Sebagaimana telah dibahas sebelumnya bahwa proses pengempaan dan pengeringan venir pada percobaan pertama terjadi secara bersamaan pada satu unit mesin 
(press dryer) dan kadar air venir setelah melalui perlakuan tersebut sekitar $6 \%$ lebih rendah, serta kehilangan volumetris yang lebih tinggi daripada percobaan kedua.

Nilai kadar air pada panel 7-lapis lebih rendah daripada kadar air panel 11-lapis (Tabel 2). Sebaliknya nilai kerapatan pada panel 7-lapis lebih tinggi daripada kerapatan panel 11-lapis. Perbedaan kedua sifat fisis tersebut tampak konsisten pada percobaan pertama maupun percobaan kedua. Perbedaan sifat ini menurut Anonim (2008) merupakan suatu kecenderungan teknis yang lazim dijumpai dalam proses produksi panel kayu lapis, sebagai akibat dari proses pengempaan panas (bot pressing) terhadap karakteristik panel. Panel kayu lapis yang terbuat dari kondisi venir yang sama akan mengalami penurunan kadar air dan peningkatan kerapatan dengan berkurangnya jumlah lapisan pada panel.

Kadar air pada panel kayu lapis sawit mengalami peningkatan dengan pertambahan komposisi venir sawit (Tabel 2). Hal ini menunjukkan bahwa venir kayu sawit bersifat lebih higroskopis dibandingkan dengan venir kayu kamper yang digunakan sebagai komponen kombinasi dalam penelitian ini. Karakteristik tersebut berkaitan dengan sifat dasar kayu sawit yang memiliki kadar air lebih tinggi dari kayu tradisional dari hutan alam maupun tanaman, sehingga secara alami kayu sawit memiliki tempat ikatan air (water sorption sites) lebih banyak daripada kayu lainnya (Balfas, 1998).

Karakteristik mekanis panel kayu lapis sawit disajikan pada Tabel 4. Nilai keteguhan rekat pada panel kayu sawit secara nyata dipengaruhi oleh faktor proses percobaan, jumlah lapisan, komposisi lapisan, serta kombinasi ketiga faktor tersebut (Tabel 5). Keragaman nilai keteguhan rekat pada panel kayu sawit mengikuti pola keragaman pada nilai kerapatan panel. Kedua parameter ini memiliki korelasi yang sangat erat ( $>>99 \%$ ) dengan koefisien korelasi $\left(R^{2}\right)$ sebesar 0,884 . Hal ini berarti nilai keteguhan rekat pada panel kayu lapis sawit mengalami peningkatan dengan pertambahan nilai kerapatan panel. Fenomena serupa telah dilaporkan oleh Santoso dan Sutigno (2004) pada panel kayu lapis kapur.

\section{Tabel4. Sifat mekanis kayu lapis sawit}

\section{Table 4. Mechanical properties of oil palm plywood}

\begin{tabular}{|c|c|c|c|c|c|}
\hline $\begin{array}{c}\text { Percobaan } \\
\text { (Experiment) }\end{array}$ & $\begin{array}{l}\text { Jumlah lapisan } \\
\text { (Number of } p l y)\end{array}$ & $\begin{array}{c}\text { Komposisi lapisan } \\
\text { (Ply composition) }\end{array}$ & $\begin{array}{c}\mathrm{KR} \\
\mathrm{Kg} / \mathrm{cm}^{2}\end{array}$ & $\begin{array}{l}\text { KK } \\
(\%)\end{array}$ & $\begin{array}{l}\text { Del } \\
(\%)\end{array}$ \\
\hline \multirow{6}{*}{ I } & \multirow{3}{*}{7 Lapis (Plies) } & 82 & 6,854 & 100 & 0 \\
\hline & & 92 & 6,907 & 100 & 0 \\
\hline & & 100 & 7,021 & 100 & 0 \\
\hline & \multirow{3}{*}{11 Lapis (Plies) } & 82 & 6,305 & 100 & 0 \\
\hline & & 92 & 6,412 & 100 & 0 \\
\hline & & 100 & 6,299 & 100 & 0 \\
\hline \multirow{6}{*}{ II } & \multirow{3}{*}{7 Lapis (Plies) } & 82 & 6,136 & 100 & 0 \\
\hline & & 92 & 6,218 & 100 & 0 \\
\hline & & 100 & 6,186 & 100 & 0 \\
\hline & \multirow{3}{*}{11 Lapis (Plies) } & 82 & 5,672 & 100 & 0 \\
\hline & & 92 & 5,689 & 100 & 0 \\
\hline & & 100 & 5,706 & 100 & 0 \\
\hline
\end{tabular}

Keterangan (Remarks): KR = Keteguhan rekat (Bond strength); KK = Kerusakan kayu (Wood failure); Del $=$ Delaminasi $($ Delamination $)$ 
Nilai keteguhan geser rekatan pada Tabel 4 secara umum memiliki nilai keteguhan lebih rendah daripada batasan minimal yang ditetapkan dalam standar Jepang $\left(7 \mathrm{Kg} / \mathrm{cm}^{2}\right)$. Hal ini berarti bahwa kualitas rekatan pada panel kayu lapis sawit lebih rendah daripada rekatan pada panel kayu lapis sengon yang dilaporkan oleh Iskandar (2006). Namun demikian, panel kayu lapis sawit memiliki nilai kerusakan kayu dan delaminasi masing-masing sebesar 100 dan $0 \%$, sehingga menurut standar tersebut panel kayu lapis sawit dapat digunakan untuk keperluan interior.

Tabel 5. Analisis keragaman pada sifat mekanis panel kayu lapis sawit Table 5. Analysis of variances on mechanical properties of oil palm plywood

\begin{tabular}{|c|c|c|c|c|}
\hline \multirow[b]{2}{*}{$\begin{array}{c}\text { Sumber keragaman } \\
\text { (Source of variances) }\end{array}$} & \multirow[b]{2}{*}{$\begin{array}{l}\mathrm{db} \\
(d f)\end{array}$} & \multicolumn{3}{|c|}{ F- Hitung (F-Calculated) } \\
\hline & & $\begin{array}{l}\text { Keteguhan rekat } \\
\text { (Bond strength) }\end{array}$ & $\begin{array}{c}\text { Kerusakan kayu } \\
\text { (Wood failure) }\end{array}$ & $\begin{array}{c}\text { Delaminasi } \\
\text { (Delamination) }\end{array}$ \\
\hline $\begin{array}{l}\text { EXP }=\text { Percobaan } \\
\text { (Experiment) }\end{array}$ & 1 & $308,710^{\text {sn }}$ & $0^{\text {tn }}$ & $0^{\text {tn }}$ \\
\hline $\begin{array}{l}\text { NUMBER = Jumlah } \\
\text { lapisan } \\
(\text { Number of ply) }\end{array}$ & 1 & 174,661 sn & $0^{\text {tn }}$ & $0^{\text {tn }}$ \\
\hline $\begin{array}{l}\text { COMP = Komposisi } \\
\text { lapisan } \\
\text { (Composition of ply) }\end{array}$ & 2 & $0,920^{\mathrm{sn}}$ & $0^{\text {tn }}$ & 0 tn \\
\hline $\mathrm{EXP} * \mathrm{NUMBER}$ & 1 & 1,448 sn & $0^{\text {th }}$ & $0^{\text {tn }}$ \\
\hline $\mathrm{EXP} * \mathrm{COMP}$ & 2 & $0,134^{\text {tn }}$ & $0^{\text {tn }}$ & $0^{\text {tn }}$ \\
\hline NUMBER * COMP & 2 & 0,897 sn & $0^{\text {tn }}$ & $0^{\text {tn }}$ \\
\hline $\begin{array}{l}\text { EXP } * \text { NUMBER * } \\
\text { COMP }\end{array}$ & 2 & 0,659 sn & $0^{\text {tn }}$ & $0^{\text {tn }}$ \\
\hline Galat (Error) & 48 & & & \\
\hline
\end{tabular}

Nilai kerusakan kayu dan delaminasi pada semua panel kayu lapis sawit masing-masing menunjukkan nilai yang sama (Tabel 4). Nilai kerusakan kayu pada panel sebesar $100 \%$ menunjukkan bahwa nilai keteguhan rekatan pada panel tersebut sesungguhnya menggambarkan nilai keteguhan geser pada venir kayu sawit. Artinya keteguhan rekat pada garis rekatan (bonding line) dapat mencapai lebih dari nilai yang tercantum pada Tabel 4, karena pada garis rekatan tersebut tidak terjadi kerusakan.

Dengan demikian kelemahan yang dijumpai pada kualitas rekatan panel kayu lapis sawit terletak pada kelemahan struktur kayu sawit. Kelemahan ini terutama berhubungan dengan porsi jaringan non struktural (parenkimatos) dalam jumlah yang besar pada struktur anatomi kayu sawit (Balfas, 2006). Perlakuan impregnasi resin organik kedalam struktur kayu monokotil dapat menyempurnakan karakteristik fisis maupun mekanis kayu tersebut (Balfas, 2007). 


\section{KESIMPULAN DAN SARAN}

\section{A. Kesimpulan}

1. Batang sawit dapat dimanfaatkan untuk pembuatan panel kayu lapis dengan menggunakan fasilitas konvensional yang terdapat pada industri kayu lapis.

2. Percobaan produksi venir kayu sawit menghasilkan rendemen venir basah sebesar 42 sampai dengan $63 \%$ tergantung fasilitas dalam proses produksi.

3. Peningkatan efisiensi dan produktivitas dalam pembuatan venir dan panel kayu lapis sawit dapat dilakukan melalui beberapa modifikasi pada mesin dan peralatan yang digunakan dalam proses produksi.

4. Kualitas panel kayu lapis sawit secara nyata dipengaruhi oleh faktor proses percobaan, jumlah lapisan dan komposisi lapisan.

5. Keteguhan rekat pada kayu lapis sawit memiliki korelasi positif dengan nilai kerapatannya.

6. Panel kayu lapis sawit relatif kurang stabil dan memiliki kualitas rekatan lebih rendah dibandingkan dengan panel kayu lapis sengon.

7. Mengacu pada standar Jepang (JAS) kayu lapis sawit hanya memenuhi persyaratan panel interior.

\section{B. Saran}

1. Percobaan pemanfaatan batang kayu sawit untuk produksi kayu lapis menunjukkan hasil produk yang cukup baik, namun masih banyak hal yang perlu disempurnakan melalui modifikasi mesin, peralatan, serta tahapan dalam proses produksi, sehingga kegiatan produksi dapat dilakukan secara lebih praktis dan efisien, serta pencapaian kualitas produk yang lebih tinggi.

2. Kelemahan pada struktur anatomi kayu sawit perlu disempurnakan melalui suatu proses densifikasi yang lebih efektif agar diperoleh stabilitas dimensi dan keteguhan rekat panel yang lebih sempurna.

\section{DAFTAR PUSTAKA}

Anonim. 1993. Japanese Agricultural Standard for Structural Plywood. Japan Plywood Inspection Corporation, Tokyo.

. 2008. Plywood Design Fundamentals. Canadian Plywood Association. Canada.

Balfas, J. 1998. Sifat dasar kayu sawit. Prosiding Diskusi Nasional Hutan Rawa dan Ekspose Hasil Penelitian di Sumatra Utara. Medan 18-19 September 1998. Balai Penelitian Kehutanan. Pematang Siantar.

,2006. New approach to oil palm wood utilization for wood working production, Part 1: Basic properties. Journal of Forestry Research 3(1):55-66. Forestry Research and Development Agency. Jakarta. 
2007. Perlakuan resin pada kayu kelapa. Jurnal Penelitian Hasil Hutan. 25(2):108118. Pusat Penelitian dan Pengembangan Hasil Hutan. Bogor.

Haygeen, J.G. and L. Bowyer. 1985. Forest Products and Wood Science. Second Printing. The IOWA State University Press, Ames.

Iskandar, M.I. 2006. Pemanfaatan kayu hutan rakyat sengon (Paraserianthes falcataria (L) Nielsen) untuk kayu rakitan. Prosiding Seminar Hasil Litbang Hasil Hutan 2006. Bogor, 21 September 2006; 142-150. Pusat Penelitian dan Pengembangan Hasil Hutan, Bogor.

Purwanto, B.E. 2008. Alokasi bahan baku kayu untuk keperluan domestik. Prosiding seminar hasil litbang hasil hutan. Bogor, 25 Oktober 2008; 7-15. Pusat Penelitian dan Pengembangan Hasil Hutan, Bogor.

Santoso, A. dan P. Sutigno. 2004. Pengaruh tepung gaplek dan dekstrin sebagai ekstender perekat urea formaldehida terhadap keteguhan rekat kayu lapis kapur. Jurnal Penelitian Hasil Hutan. 22(2):61-68. Pusat Penelitian dan Pengembangan Teknologi Hasil Hutan, Bogor. 